\title{
Kemampuan Dosen dalam Membuat Soal HOTS Pada Pembelajaran Abad 21
}

\author{
Ahmad Ali ${ }^{\left.{ }^{*}\right)}$, Wiwin Pramita Arif ${ }^{1)}$, Ilmi Zajuli Ichsan ${ }^{2,3)}$, Diana Vivanti Sigit ${ }^{4)}$, \\ Rahmawati Darussyamsu $^{5)}$, Dasmo ${ }^{6}$, Nurfadhilah ${ }^{7)}$, Nur Fadli Hazhar Fachrial ${ }^{8)}$ \\ ${ }^{1)}$ Pendidikan Biologi, Universitas Islam Negeri Alauddin Makassar, Indonesia \\ ${ }^{2)}$ Pendidikan Guru Sekolah Dasar, Universitas MH Thamrin Jakarta, Indonesia \\ ${ }^{3}$ )Pendidikan Kependudukan dan Lingkungan Hidup, Universitas Negeri Jakarta, Indonesia \\ ${ }^{4)}$ Pendidikan Biologi, Universitas Negeri Jakarta, Indonesia \\ ${ }^{5}$ Pendidikan Biologi, Universitas Negeri Padang, Indonesia \\ ${ }^{6}$ Pendidikan Fisika, Universitas Indraprasta PGRI, Indonesia \\ $\left.{ }^{7}\right)$ Kesehatan masyarakat, Universitas Muhammadiyah Jakarta, Indonesia \\ ${ }^{8}$ ) Pendidikan Guru Sekolah Dasar, STKIP Arrahmaniyah, Indonesia \\ *ahmad.ali@uin-alauddin.ac.id
}

\begin{abstract}
Twenty-first century learning requires high-level thinking skills including critical thinking, communication, collaboration, and creativity known as the 4Cs. The purpose of this study was to determine the ability of the lecturers of the Biology Education Study Program at UIN Alauddin Makassar in making Higher Order Thinking Skills (HOTS) questions and to find out the responses of the lecturers of the Biology Education Study Program at UIN Alauddin Makassar on the importance of developing HOTS questions. This research is a quantitative descriptive research. This research was carried out in the odd semester of the 2019/2020 Academic Year with the research subjects of all lecturers of the Biology Education Study Program at UIN Alauddin Makassar who have educational backgrounds according to the study program as many as 12 people. Data collection techniques through question documentation and questionnaires. Data were analyzed by descriptive statistics. The results showed that Lecturers of the Biology Education Study Program were able to make higher order thinking questions (HOTS) with a percentage of $33 \%$ Very Able, $8 \%$ Able, and $17 \%$ Enough, while the remaining $42 \%$ with the criteria of Poor. As many as $85 \%$ of the Lecturers of the Biology Education Study Program at UIN Alauddin Makassar gave a positive response to $74 \%$ of items stating the importance of making higher order thinking questions (HOTS). Suggestions from this study was that Biology Education lecturers can innovate HOTS-based educational evaluations.
\end{abstract}

Keywords : HOTS, Lecturer ability, The 21st century skills.

This is an open access article distributed under the Creative Commons 4.0 Attribution License, which permits unrestricted use, distribution, and reproduction in any medium, provided the original work is properly cited. $\$ 2021$ by author.

\section{PENDAHULUAN}

Pembelajaran yang bermakna harus dicipta kan pada perguruan tinggi melalui pembelajaran yang aktif, kreatif, kritis, dan menyenangkan. Sesuai tuntutan pembelajaran abad 21. Pembe lajaran saat ini menggunakan kurikulum dengan menggunakan pendekatan saintifik (Haciemi noglu, 2016; Quiroga \& Choate, 2019). Hal ini menjadi pekerjaan rumah bagi dosen agar pembelajaran yang disajikan harus menyenang kan namun memberikan efek kritis dan kreatif bagi setiap mahasiswa (Ichsan \& Rahmayanti, 2020). Melatihkan berpikir kritis dan kreatif mahasiswa tidak cukup hanya pada proses Pendidikan, tetapi juga perlu dilatihkan pada proses penilaian.
Penilaian hasil belajar saat ini menitik beratkan pada kemampuan Higher Order Thinking Skills (HOTS) yang dibutuhkan pada abad 21 mengadaptasi Standar penilaian inter nasional secara bertahap. (Abidinsyah et al., 2019; Saputri et al., 2019). Evaluasi terhadap HOTS ini sangat penting dan diperlukan data yang valid dalam setiap evaluasi.

Pengambilan keputusan terhadap hasil belajar dilakukan melalui analisis data yang akurat, sehingga dapat ditarik kesimpulan bahwa mahasiswa belajar baik atau tidak, sukses atau tidak. Dengan alasan ini, diperlukan hadirnya alat tes yang baik untuk memperoleh data yang akurat (Subali, 2010). Kecenderungan kesalahan penaf siran hasil tes terjadi jika kualitas soal belum 
diketahui secara pasti. Untuk mengukur pencapai an kompetensi mahasiswa, maka sangat diperlu kan analisis kualitas butir soal (Ichsan et al., 2019). Mahasiswa juga harus dilatihkan menye lesaikan soal-soal HOTS yang sifatnya menuntut analisis, evaluasi, dan kreativitas yang tinggi (Dewi \& Riandi, 2016; Ichsan et al., 2019).

Menurut Taksonomi Anderson bahwa proses kognitif terbagi menjadi kemampuan berpikir tingkat rendah (Lower Order Thinking) dan kemampuan berpikir tingkat tinggi (Higher Order Thinking). Kemampuan yang termasuk LOT adalah kemampuan mengingat (remember), memahami (understand), dan menerapkan (apply), sedangkan Domain proses kognitif yang termasuk dalam kemampuan berpikir tingkat tinggi (High Order Thinking) adalah domain analisis (analyze), evaluasi (evaluate) dan mencipta (create)yang kesemuanya perlu dilatih (Anderson et al., 2001).

HOTS mengukur kecakapan berpikir kreatif, kritis, dan memecahkan masalah. Berpikir kreatif menghasilkan gagasan baru yang orisinil melalui proses berpikir yang rumit. Berpikir kritis yaitu mampu menganalisis, mengevaluasi, dan menggunakan kriteria secara obyektif. Kemampuan untuk memecahkan suatu masalah dengan berpikir secara kompleks dan mendalam (Gunawan, 2003). Dosen dalam hal ini memiliki peran untuk bisa membuat berbagai evaluasi berbasis HOTS untuk jenjang univer sitas. Kompetensi dosen adalah kemampuan seorang dosen dalam melaksanakan segala kewajibannya dengan rasa bertanggung jawab dan menguasai berbagai materi yang ingin disampaikan (Muhlisin et al., 2016; Winarno et al., 2017). Selain itu, harus mampu melakukan penilaian terutama penilaian yang berbasis HOTS

Berdasarkan hasil wawancara dan doku mentasi soal, masih terdapat dosen dalam membuat soal kurang memerhatikan tingkatan kognitif dari soal tersebut. Terlebih lagi untuk membuat soal yang merangsang kemampuan HOTS mahasiswa masih kurang. Padahal bahan ajar yang menunjang kegiatan perkuliahan telah menyajikan berbagai materi perkuliahan yang mampu mengajak mahasiswa untuk belajar aktif dengan konsep materi yang sistematis. Namun, dalam kegiatan penilaian atau evaluasinya terkhusus soal-soal yang dibuat oleh Dosen masih kurang dalam melatih keterampilan berpikir tingkat tinggi mahasiswa. Berdasarkan latar belakang yang telah diuraikan, maka perlu dikaji mengenai kemampuan dosen dalam membuat Soal HOTS pada program studi Pendidikan Biologi.

\section{METODE PENELITIAN}

Penelitian ini dilaksanakan di Prodi Pendi dikan Biologi Semester Ganjil Tahun Akademik 2019/2020 dengan populasi seluruh dosen Prodi Pendidikan Biologi. Teknik purposive sampling digunakan dalam menentukan sampel dengan kriteria dosen yang memiliki latar belakang keilmuan sesuai program studi sebanyak 12 Orang. Dosen tersebut mengampu berbagai mata kuliah mulai dari Fisiologi, Ekologi, ilmu lingkungan, Anatomi, dan mata kuliah lainnya yang ada di Pendidikan Biologi.

Instrumen yang digunakan dalam peneliti an ini adalah dokumentasi dan kuesioner dan telah divalidasi. Dokumentasi berupa lembar soal yang telah dibuat dosen. Kuesioner diberikan kepada dosen sebagai responden untuk mengum pulkan data tentang tanggapan dalam membuat Soal HOTS.

Lembar soal yang telah dikumpulkan dari setiap dosen Program Studi pendidikan biologi kemudian dianalisis menggunakan rubrik dengan mengacu pada kriteria soal HOTS yang diadap tasi dari Instrumen Telaah Soal HOTS oleh Kementerian Pendidikan dan Kebudayaan. Data yang terkumpul kemudian dianalisis untuk mengetahui persentase jumlah soal HOTS yang dibuat oleh dosen. Soal ditelaah oleh 3 orang ahli untuk menilai materi, konstruksi, dan tata bahasa soal yang dibuat oleh dosen. Kategori soal LOTS jika soal mengukur level kognitif C1, C2, C3 dan soal bersifat HOTS jika mengukur level kognitif C4, C5, C6

Tabel 1. Klasifikasi dan Persentase Kesesuaian butir

\begin{tabular}{ll}
\hline Persentase & Kategori \\
\hline $0 \%-25 \%$ & Tidak sesuai \\
$26 \%-50 \%$ & Kurang sesuai \\
$51 \%-75 \%$ & Sesuai \\
$76 \%-100 \%$ & Sangat sesuai \\
\hline
\end{tabular}

Adapun untuk angket tersebut dilakukan sebuah analisis secara deskriptif persentase:

$P=F /{ }_{N} x 100 \%$

Keterangan:

$\mathrm{P}=$ Persentase

$\mathrm{F} \quad=$ Frekuensi jawaban

$\mathrm{N}=$ Nilai yang diharapkan

$100 \%=$ Nilai mutlak 
Ahmad Ali, Wiwin Pramita Arif, Ilmi Zajuli Ichsan, Diana Vivanti Sigit,

Rahmawati Darussyamsu, Dasmo, Nurfadhilah, Nur Fadli Hazhar Fachrial

Untuk mengetahui kategori respon dosen digunakan klasifikasi Arikunto (2002), sebagai berikut:

Tabel 2. Klasifikasi dan Persentase respon dosen

\begin{tabular}{ll}
\hline Persentase & Kategori \\
\hline $80 \%$ & Sangat baik \\
$70 \%$ & Baik \\
$60 \%$ & Sedang \\
$<59 \%$ & Kurang baik \\
\hline
\end{tabular}

\section{HASIL DAN PEMBAHASAN}

Jumlah butir soal keseluruhan dari 12 dosen yang membuat soal sebanyak 135 butir. Diketahui $54 \%$ butir soal berbentuk uraian dan sisanya $46 \%$ soal bentuk pilihan ganda. Sementara itu dari 12 orang dosen yang membuat soal terdapat 10 dosen yang membuat soal uraian dengan persentase $83 \%$ dan 2 orang membuat soal pilihan ganda dengan persentase $17 \%$. Soal yang berjumlah 135 butir kemudian ditelaah oleh 2 orang ahli untuk menilai materi, konstruksi, bahasa, dan unsur soal tidak menggunakan unsur SARAPPPK (Suku, Agama, Ras, Antar golong an, Pornografi, Politik, Propaganda, dan Kekerasan).

Berdasarkan hasil analisis telaah soal diperoleh gambaran kualitas soal yang dibuat oleh masing-masing dosen Program Studi Pendidikan Biologi yang terdiri atas tiga aspek utama meliputi materi, konstruksi, dan bahasa serta satu aspek tambahan yakni soal tidak mengandung unsur SARAPPPK. Soal uraian buatan dosen Program Studi Pendidikan Biologi UIN Alauddin Makassar telah memenuhi kaidah penulisan soal bentuk uraian dengan persentase sebesar $83 \%$ pada kategori sangat sesuai. Jika dilihat dari masing-masing aspek diketahui bahwa aspek materi masih berada pada kategori kurang sesuai dengan persentase $43 \%$. Indikator yang masih kurang sesuai terdapat pada pembuatan stimulus dan rubrik penskoran. Ada $100 \%$ dosen dari aspek konstruksi, Bahasa, dan unsur SARAPPPK telah membuat soal sesuai dengan kaidah penyusunan soal dengan kese suaian masing-masing sebesar $100 \%$. Sedangkan pada aspek materi hanya $17 \%$ dosen yang membuat soal uraian dengan kaidah yang sangat sesuai dan masih terdapat $25 \%$ dosen membuat soal tidak sesuai kaidah penulisan.

Selain membuat soal uraian, terdapat 2 dosen Program Studi pendidikan biologi UIN
Alauddin Makassar yang membuat soal bentuk pilihan ganda sebanyak 62 butir soal. Soal tersebut ditelaah menggunakan kaidah penulisan soal bentuk pilihan ganda. Soal pilihan ganda buatan dosen Program Studi Pendidikan biologi UIN Alauddin Makassar telah memenuhi kaidah penulisan soal bentuk pilihan ganda dengan persentase sebesar $86 \%$ pada kategori sangat sesuai. Jika dilihat dari masing-masing aspek diketahui bahwa aspek materi berada pada kategori sesuai dengan persentase $56 \%$. Indikator yang masih tidak sesuai terdapat pada pembuatan stimulus yang menarik dan menyusun kebaruan. Berikut histogram persentase dosen yang membuat soal pilihan ganda jika ditinjau dari masing-masing indikator. Seluruh dosen telah mampu membuat soal sesuai kaidah penyusunan soal pilihan ganda dengan kesesuaian $100 \%$ pada bagian Konstruksi, bahasa, dan unsur SARAPPPK. Sedangkan unsur materi berada pada kategori sesuai dengan persentase $100 \%$.

Soal buatan dosen Program Studi Pendi dikan Biologi UIN Alauddin Makassar dibuat dalam dua bentuk yakni pilihan ganda dan bentuk uraian. Jumlah dosen yang membuat soal sebanyak 12 orang dan hanya 2 orang dosen yang membuat bentuk soal pilihan ganda. Berdasarkan tanggapan pada angket respon dosen diperoleh informasi bahwa soal urain dipilih karena lebih mudah membuatnya, dapat merangsang analisis dan kritis mahasiswa, dapat mengetahui kedalam pengetahuan mahasiswa terhadap suatu topik karena jawabannya terbuka. Menurut (Pratiwi, 2015) soal uraian memberikan kesempatan kepada peserta tes untuk mengungkapkan pendapatnya secara bebas. Selain itu, soal bentuk uaraian akan meminimalisir kecurangan peserta tes selama ujian berlangsung. Kelemahan dari soal uraian terletak dari penskoran yang masih rentang dipengaruhi unsur subjektivitas (Nursalam, 2014), sehingga diperlukan rubrik yang rinci dan jelas. Kebalikan dari soal uraian, soal bentuk pilihan ganda lebih mudah dalam memeriksa dan pengerjaannya dapat diserahkan kepada orang lain (Nursalam, 2012), tetapi pengerjaan soal pilihan ganda memungkinkan peserta tes hanya menebak jawaban dan tidak merepresentasikan tingkat pengetahuan peserta tes. Selain itu, soal pilihan ganda sarat kecurang an oleh peserta tes dengan saling membagi jawaban dengan kode-kode tertentu misalnya menggunakan tangan.

Hasil analisis butir soal uraian buatan dosen Program Studi pendidikan biologi UIN 
Alauddin Makassar menunjukkan kesesuaian kaidah penulisan soal dengan persentase $83 \%$. Penilaian pada aspek materi menunjukkan kesesuaian hanya 43\%. Hal ini disebabkan beberapa indikator tidak terpenuhi oleh dosen. Misalnya; soal tidak memiliki rubrik penskoran. Hal ini disebabkan karena peneliti hanya mendokumentasikan soal buatan dosen tanpa meminta rubrik penskorannya. Namun angket respon menunjukkan bahwa $75 \%$ dosen membuat rubrik penskoran. Rubrik biasanya langsung dibu at setelah soal selesai disusun (Nursalam, 2012).

Indikator yang belum maksimal juga terlihat dari kemampuan dosen membuat stimu lus yang kontekstual dan menarik. Hal ini sangat bersesuaian dengan level kognitif soal yang dibuat. Soal level C1, C2, dan C3 tidak menunjukkan stimulus pada kalimat soalnya. Soal level berpikir tingkat tinggi (HOTS) biasanya mengandung stimulus sebagai dasar membuat pertanyaan. Kualitas dan variasi stimulus sangat dipengaruhi oleh kreativitas pendidik dalam hal ini dosen (Fanani, 2018).

Soal uraian buatan dosen jika dilihat dari aspek konstruksi, Bahasa, dan unsur SARAPPPK telah sesuai dengan kaidah penyusunan soal. Diketahui bahwa semua dosen (100\%) mampu membuat soal dengan konstruksi dan bahasa yang sesuai. Namun jika melihat hasil telaah butir soal uraian, dosen masih kurang menggunakan gambar, grafik, tabel, diagram, atau sejenisnya dalam menyusun soal sebagai stimulus. Padahal sangat dibutuhkan dalam menuntut mahasiswa dalam berpikir tingkat tinggi (Lailly \& Wisudawati, 2015).

Hasil analisis butir soal pilihan ganda buatan dosen Program Studi pendidikan biologi UIN Alauddin Makassar menunjukkan kesesuai an kaidah penulisan soal dengan persentase $86 \%$.
Soal buatan dosen jika dilihat dari aspek konstruksi, Bahasa, dan unsur SARAPPPK telah sesuai dengan kaidah penyusunan soal. Diketahui bahwa semua dosen (100\%) mampu membuat soal dengan konstruksi dan bahasa yang sesuai, namun jika melihat hasil telaah butir soal pilihan ganda, masih terdapat gambar pada soal yang tidak berfungsi. Selain itu, masih terdapat pernyataan soal yang mengarahkan ke kunci jawaban. Pernyataan soal menjadi tidak komuni katif yang menyebabkan pengecoh tidak ber fungsi (Nofiana, 2015).

Penilaian pada aspek materi menunjukkan kesesuaian 56\%. Hal ini disebabkan beberapa indikator tidak terpenuhi oleh dosen. Dosen masih kesulitan membuat stimulus yang menarik. Selain itu, masih terdapat soal pilihan ganda buatan dosen yang belum mengukur level penalaran. Indikator yang masih kurang sesuai juga terlihat dari rumusan soal dosen yang tidak mengusung kebaruan. Hal ini disebabkan oleh karakteristik mata kuliah yang diajarkan oleh para dosen. Misalnya mata kuliah struktur hewan dan struktur tumbuhan tingkat tinggi. Karakteris tik mata kuliah yang lebih banyak mengukur level kognitif $\mathrm{C} 1, \mathrm{C} 2$, dan C3 saja.

Soal buatan dosen selanjutnya dipersen tasekan berdasarkan level kognitif masingmasing butir soal berdasarkan taksonomi Bloom yang telah direvisi oleh Anderson. Level kognitif meliputi C1 (mengetahui), C2 (memahami), C3 (menerapkan), C4 (menganalisis), C5 (mengeva luasi), dan C6 (Mencipta). Soal dianggap bersifat LOTS jika mengukur level kognitif C1, C2, C3 dan soal dianggap bersifat HOTS jika mampu mengukur level kognitif C4, C5, C6. Analisis kualitas soal berdasarkan level kognitif dapat dilihat pada Tabel 3 .

Tabel 3. Persentase kemampuan dosen Program Studi Pendidikan Biologi

\begin{tabular}{|c|c|c|c|c|c|c|c|c|c|}
\hline \multirow{2}{*}{ Dosen } & \multicolumn{3}{|c|}{ Soal LOTS (\%) } & \multirow{2}{*}{$\begin{array}{c}\% \\
\text { LOTS }\end{array}$} & \multicolumn{3}{|c|}{ Soal HOTS (\%) } & \multirow{2}{*}{$\begin{array}{c}\% \\
\text { HOTS }\end{array}$} & \multirow[t]{2}{*}{ Ket. } \\
\hline & $\mathrm{C} 1$ & $\mathrm{C} 2$ & $\mathrm{C} 3$ & & $\mathrm{C} 4$ & $\mathrm{C} 5$ & C6 & & \\
\hline $\mathrm{A}$ & 31 & 49 & 14 & 94 & 6 & 0 & 0 & 6 & $\mathrm{KM}$ \\
\hline B & 0 & 41 & 3 & 44 & 56 & 0 & 0 & 56 & $\mathrm{M}$ \\
\hline $\mathrm{C}$ & 0 & 0 & 0 & 0 & 0 & 0 & 100 & 100 & SM \\
\hline $\mathrm{D}$ & 0 & 80 & 20 & 100 & 0 & 0 & 0 & 0 & $\mathrm{KM}$ \\
\hline $\mathrm{E}$ & 0 & 0 & 0 & 0 & 100 & 0 & 0 & 100 & SM \\
\hline $\mathrm{F}$ & 0 & 100 & 0 & 100 & 0 & 0 & 0 & 0 & $\mathrm{KM}$ \\
\hline $\mathrm{G}$ & 0 & 100 & 0 & 100 & 0 & 0 & 0 & 0 & $\mathrm{KM}$ \\
\hline $\mathrm{H}$ & 0 & 0 & 0 & 0 & 70 & 20 & 10 & 100 & SM \\
\hline I & 0 & 57 & 14 & 71 & 29 & 0 & 0 & 29 & $\mathrm{CM}$ \\
\hline
\end{tabular}


Ahmad Ali, Wiwin Pramita Arif, Ilmi Zajuli Ichsan, Diana Vivanti Sigit,

Rahmawati Darussyamsu, Dasmo, Nurfadhilah, Nur Fadli Hazhar Fachrial

\begin{tabular}{cccccrrrrr} 
J & 0 & 100 & 0 & 100 & 0 & 0 & 0 & 0 & KM \\
K & 0 & 50 & 0 & 50 & 17 & 17 & 17 & 50 & CM \\
L & 0 & 20 & 0 & 20 & 60 & 20 & 0 & 80 & SM \\
Jumlah & 31 & 597 & 52 & 680 & 337 & 57 & 127 & 520 & \\
Rata-Rata & 3 & 50 & 4 & 57 & 28 & 5 & 11 & 43 & \\
\hline
\end{tabular}

Keterangan: Sangat Memuaskan (SM), Memuaskan (M), Cukup Memuaskan (CM), Kurang Memuaskan (KM)

Berdasarkan Tabel 1 diketahui bahwa 57\% soal yang dibuat oleh dosen Program Studi Pendidikan Biologi UIN Alauddin Makassar masih bersifat LOTS dengan masing-masing $\mathrm{C} 1$ (mengingat) 3\%, C2 (memahami) 50\%, dan C3 (menerapkan) 4\%. Sementara itu, terdapat $43 \%$ soal yang dibuat dosen Program Studi Pendidik an Biologi sudah bersifat HOTS dengan kualitas masing-masing C4 (menganalisis) 28\%, C5 (mengevaluasi) 5\%, dan C6 (mencipta) $10 \%$.

Sementara itu, dari 12 dosen Program Studi Pendidikan Biologi yang diminta membu at soal terdapat 4 dosen yang tidak membuat soal HOTS dengan persentase $33 \%$, sementara itu terdapat 3 dosen yang keseluruhan soal yang dibuat bersifat HOTS dengan persentase $17 \%$. Diagram kemampuan dosen pendidikan Biologi UIN Alauddin membuat soal HOTS dapat dilihat pada Gambar 1.

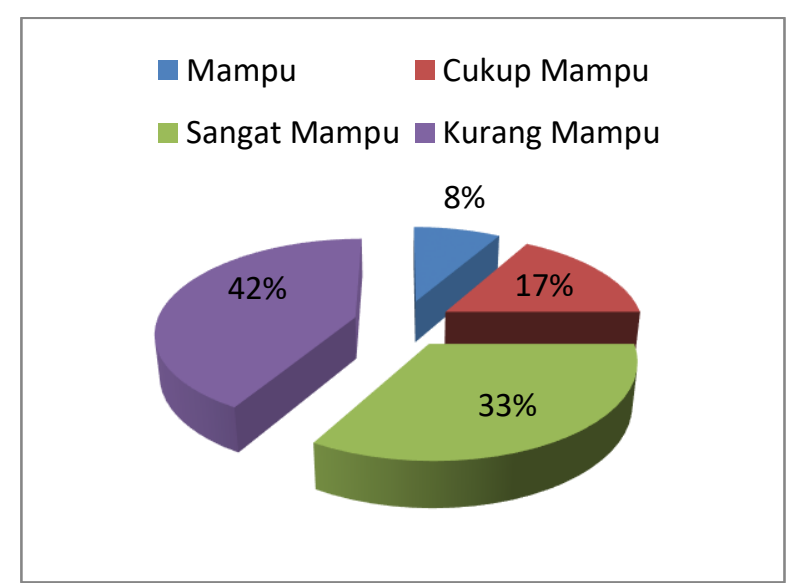

Gambar 1. Kemampuan Dosen Membuat Soal HOTS

Gambar 1 menujukkan bahwa sebagian besar dosen Program Studi Pendidikan Biologi sudah mampu membuat soal berpikir tingkat tinggi (HOTS) dengan persentase 33\% Sangat Mampu, 8\% Mampu, dan 17\% Cukup, semen tara sisanya $42 \%$ dengan kriteria Kurang Mampu.

Soal dosen didominasi soal level kognitif $\mathrm{C} 2$ (memahami) dengan persentase terbesar $50 \%$. Soal level C2 mengukur pengetahuan faktual, konseptual, dan prosedural. Tetapi tidak melibat kan proses berpikir tingkat tinggi. Melainkan hanya mengandalkan hafalan untuk menjawab nya. Ada $28 \%$ soal mengukur level kognitif C4 (menganalisis) menuntut kemampuan untuk menspesifikasi aspek-aspek/elemen, mengurai kan, membedakan, mengklasifikasi. Pada dimen si proses berpikir mengevaluasi (C5) menuntut kemampuan untuk menilai baik atau buruk, mengkritik, memberi solusi, menarik hikmah pada sebuah peristiwa. Sedangkan pada dimensi mencipta (C6) menuntut kemampuan untuk merancang, menciptakan dan mendesain hal baru. Soal HOTS yang dibuat dosen sebagai bentuk upaya pelaksanaan pembelajaran abad 21. Pembelajaran abad 21 menuntut keterampilan 4C (critical thinking, communication, collabo ration, and creativity) (Ariyana et al., 2018; Heinrichs, 2016; Lee, 2016; Sadiqin et al., 2017).

Keterampilan berpikir tingkat tinggi akan meningkat jika mahasiswa diberikan permasalah an yang harus dipecahkan (Anagun, 2018; Bruehl et al., 2015; Kinslow et al., 2018). Keterampilan tingkat tinggi meliputi kemampuan untuk memecahkan masalah (problem solving), kete rampilan berpikir kritis (critical thinking) berpikir kreatif (creative thinking), kemampuan berargumen (reasoning), dan kemampuan mengambil keputusan (decision making) (Dubas \& Toledo, 2016; Heong et al., 2012; Isbandiyah \& Sanusi, 2019; Yee et al., 2015). Keterampilan tingkat tinggi dapat dilatihkan kepada mahasiswa dengan pembisaan pemberian soal HOTS dalam proses pembelajaran.

Dosen Program Studi Pendidikan Biologi setelah diminta membuat soal HOTS, selanjutnya diminta tanggapan terhadap penyusunan soal HOTS. Angket mengukur pemahaman dosen tentang soal HOTS, tahapan penyusunan soal HOTS, Karakteristik soal HOTS, upaya dosen meningkatkan kemampuan literasi, serta kendala yang dihadapi selama penyusunan soal. Hasil analisis angket tanggapan dosen dapat dilihat pada Gambar 4. 


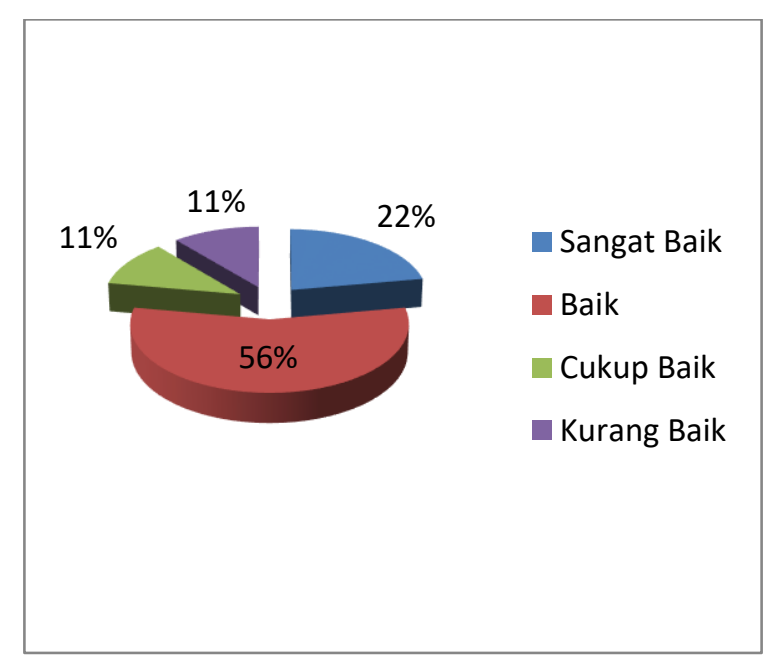

Gambar 2. Respon Dosen terhadap Pembuatan Soal HOTS

Berdasarkan analisis angket respon dosen diketahui bahwa $85 \%$ dosen pendidikan biologi UIN Alauddin Makassar memberikan respon yang positif terhadap pentingnya pembuatan soal HOTS terhadap $74 \%$ item pernyataan. Hasil analisis menujukkan bahwa dosen masih kesulitan merumuskan stimulus yang tepat serta tidak membuat kartu soal. Selain itu masih terdapat dosen yang merasa kesulitan dalam membuat rubrik penskoran.

Hasil analisis angket respon menunjukkan bahwa dosen pendidikan biologi telah menginteg rasikan pembelajaran berbasis HOTS sesuai abad 21. Aspek C4 (analisis) dapat ditingkatkan dengan menerapkan berbagai metode, strategi, dan media pembelajaran yang dapat merangsang daya analisis mahasiswa (Miarsyah et al., 2019; Sigit et al., 2019; Suharini et al., 2020). Aspek C5 (evaluasi) dapat ditingkatkan dengan meminta mahasiswa mendiskusikan sebuah masalah atau kasus dengan argumen dari berbagai sumber yang relevan. Aspek C6 (mencipta) ditingkatkan dengan memberikan proyek kepada mahasiswa untuk membuat sebuah produk baru, atau produk alternatif lain yang dapat memecahkan sebuah masalah yang sama. Hal ini sejalan dengan yang disampaikan oleh Priantari et al. (2020) bahwa melalui pembelajaran berbasis proyek mengguna kan pendekatan STEAM dapat meningkatkan kemampuan berpikir kritis dan kreatif peserta didik. Hal ini dapat terlaksana karena pembe lajaran berbasis proyek memberikan mahasiswa peluang untuk menerapkan kebebasan dalam belajar (Gülbahar \& Tinmaz, 2006) sehingga kreativitas mereka dalam menyelesaikan sebuah proyek dapat dilakukan secara maksimal.
Salah satu model Pembelajaran yang mampu memenuhi aspek $\mathrm{C} 4, \mathrm{C} 5$, dan $\mathrm{C} 6$ adalah model pembelajaran berbasis masalah (Problem Based Learning). PBL mengembangkan kemam puan untuk berpikir kritis, menganalisis dan menyelesaikan masalah dunia nyata yang kompleks, mengevaluasi, dan menggunakan pembelajaran yang sesuai, meningkatkan kerja sama, dan keterampilan komunikasi yang efektif (Farisi, 2016; Quieng et al., 2015; Savery, 2006)

\section{KESIMPULAN}

Dosen Program Studi Pendidikan Biologi sudah mampu membuat soal berpikir tingkat tinggi (HOTS) dengan persentase 33\% Sangat Mampu, 8\% Mampu, dan 17\% Cukup, sementara sisanya $42 \%$ dengan kriteria Kurang Mampu. Sebanyak 85\% Dosen Program Studi Pendidikan Biologi UIN Alauddin Makassar memberikan respon yang positif terhadap $74 \%$ item pernyata an pentingnya pembuatan soal HOTS. Disaran kan kepada seluruh dosen Program Studi Pendidikan Biologi UIN Alauddin Makassar agar senantiasa melaksanakan proses pembelajaran berbasis HOTS sesuai tuntutan pembelajaran abad 21 dan membuat soal berpikir tingkat tinggi (HOTS) dalam memberikan evaluasi kepada mahasiswa.

\section{UCAPAN TERIMA KASIH}

Ucapan terima kasih kepada LITABDIMAS yang telah membiayai penelitian ini melalui Lembaga Penelitian dan Pengabdian Kepada Masyarakat UIN Alauddin Makassar Tahun Anggaran 2019.

\section{DAFTAR PUSTAKA}

Abidinsyah, A., Ramdiah, S., \& Royani, M. (2019). The Implementation of Local Wisdom-Based Learning and HOTS-Based Assessment: Teacher Survey in Banjar masin. JPBI (Jurnal Pendidikan Biologi Indonesia), 5(3), 407-414.

Anagun, S. S. (2018). Teachers' Perceptions About The Relationship Between 21st Century Skills and Managing Constructivist Learning Environments. International Journal of Instruction, 11(4), 825-840.

Anderson, L. W., Krathwohl, D. R., Airiasian, W., Cruikshank, K. A., Mayer, R. E., Pintrich, P. R., Raths, J., \& Wittrock, M. C. 
Ahmad Ali, Wiwin Pramita Arif, Ilmi Zajuli Ichsan, Diana Vivanti Sigit,

Rahmawati Darussyamsu, Dasmo, Nurfadhilah, Nur Fadli Hazhar Fachrial

(2001). A Taxonomy for Learning, Teaching and Assessing: A Revision of Bloom's Taxonomy of Educational Objectives. Longman.

Ariyana, Y., Bestary, R., Yogyakarta, U. N., \& Mohandas, R. (2018). Buku Pegangan Pembelajaran Berorientasi pada Keterampilan Berpikir Tingkat Tinggi. Direktorat Jenderal Guru dan Tenaga Kependidikan.

Bruehl, M., Pan, D., \& Ferrer-Vinent, I. J. (2015). Demystifying the Chemistry Literature: Building Information Literacy in First-Year Chemistry Students Through StudentCentered Learning and Experiment Design. Journal of Chemical Education, A-F.

Dewi, N., \& Riandi, R. (2016). Analisis Kemampuan Berpikir Kompleks Siswa Melalui Pembelajaran Berbasis Masalah Berbantuan Mind Mapping. Edusains UIN Syarif Hidayatullah, 8(1), 98-107.

Dubas, J. M., \& Toledo, S. A. (2016). Taking Higher Order Thinking Seriously: Using Marzano's Taxonomy in The Economics Classroom. International Review of Econo mics Education, 21, 12-20.

Fanani, M. Z. (2018). Strategi Pengembangan Soal Hots pada Kurikulum 2013. Edudeena, 2(1), 57-76.

Farisi, M. I. (2016). Developing The 21 StCentury Social Studies Skills Through Technology Integration. Turkish Online Journal of Distance Education-TOJDE, 17(1), 16-30.

Gülbahar, Y., \& Tinmaz, H. (2006). Implementing Project-Based Learning and E-Portfolio Assessment in an Under graduate Course. Journal of Research on Technology in Education, 38(3), 309-327.

Gunawan, A. W. (2003). Genius Learning Strategy: Petunjuk Praktis untuk Menerap kan Accelerated Learning. Jakarta: PT Gramedia Pustaka Utama.

Hacieminoglu, E. (2016). Elementary School Students' Attitude Toward Science and Related Variables. International Journal of Environmental and Science Education, 11(2), 35-52.

Heinrichs, C. R. (2016). Exploring the Influence of 21st Century Skills in a Dual Language Program: A Case Study. International Journal of Teacher Leadership Heinrichs Exploring the Influence, 37(1), 37-56.

Heong, Y. M., Yunos, J., Othman, W., Hassan, R., Kiong, T. T., \& Mohamad, M. M. (2012). The Needs Analysis of Learning Higher Order Thinking Skills for Generating Ideas. Procedia - Social and Behavioral Sciences, 59, 197-203.

Ichsan, I. Z., \& Rahmayanti, H. (2020). HOTSEP: Revised Anderson's Taxonomy in Environmental Learning of COVID-19. European Journal of Educational Research, 9(3), 1257-1265.

Ichsan, I. Z., Sigit, D. V., Miarsyah, M., Ali, A., Arif, W. P., \& Prayitno, T. A. (2019). HOTS-AEP: Higher Order Thinking Skills From Elementary To Master Students in Environmental Learning. European Jour nal of Educational Research, 8(4), 935942.

Isbandiyah, S., \& Sanusi, A. (2019). Modul Penyusunan Soal Keterampilan Berpikir Tingkat Tinggi (Higher Order Thinking Skills) (L. Hhadi (ed.)). Direktorat Pembinaan Sekolah Menengah Atas.

Kinslow, A. T., Sadler, T. D., \& Nguyen, H. T. (2018). Socio-Scientific Reasoning and Environmental Literacy in A Field-Based Ecology Class. Environmental Education Research, 4622, 1-23.

Lailly, N. R., \& Wisudawati, A. W. (2015). Analisis Soal Tipe Higher Order Thinking Skill (HOTS) dalam Soal UN Kimia SMA Rayon B Tahun 2012/2013. Jurnal Kaunia, 11(1), 27-39.

Lee, A. Y. L. (2016). Media Education in The School 2.0 Era: Teaching Media Literacy Through Laptop Computers and Ipads. Global Media and China, 1(4), 435-449.

Miarsyah, M., Rusdi, R., Aryani, N. D., \& Ichsan, I. Z. (2019). MEBA: Development Android-Based Ecosystem Module for Senior High School Students. Indian Journal of Public Health Research and Development, 10(8), 2114-2118.

Muhlisin, A., Susilo, H., Amin, M., \& Rohman, F. (2016). Improving Critical Thinking 
Skills of College Students Through RMS Model For Learning Basic Concepts in Science. Asia-Pacific Forum on Science Learning and Teaching, 17(1), 1-24.

Nofiana, M. (2015). Kualitas Penulisan Butir Soal Ujian Nasional Biologi Tahun 2014/2015 ditinjau dari aspek teoritik. Saintifika, 17(1), 1-13.

Nursalam. (2012). Pengukuran dalam Pendidik an. In M. Malik (Ed.), Yogyakarta: Pustaka Pelajar (1st ed., Vol. 1, Issue 2). Alauddin University Press.

Nursalam, N. (2014). Statistika dan Pengukuran untuk Guru dan Dosen: Teori dan Aplikasinya dalam Bidang Pendidikan. Alauddin Unuversity Press.

Pratiwi, I. H. (2015). Kemampuan Guru Mata Pelajaran Ipa Dalam Pembuatan Soal HOT (Higher Order Thinking) Dan Kesesuaian Penulisan Soal Di Smp Negeri 1 Kragan Rembang. Universitas Muhammadiyah Surakarta.

Priantari, I., Prafitasari, A. N., Kusumawardhani, D. R., \& Susanti, S. (2020). Improving Students' Critical Thinking through STEAM-PjBL Learning. Bioeducation Journal, 4(2), 95-103.

Quieng, M. C., Lim, P. P., \& Lucas, M. R. D. (2015). 21st Century-Based Soft Skills: Spotlight On Non-Cognitive Skills In A Cognitive-Laden Dentistry Program. Euro pean Journal of Contemporary Education, 11(1), 72-81.

Quiroga, M. D. M., \& Choate, J. K. (2019). A Virtual Experiment Improved Students' Understanding of Physiological Experimen tal Processes Ahead Of A Live InquiryBased Practical Class. Advances in Physio logy Education, 43(4), 495-503.

Sadiqin, I. K., Santoso, U. T., \& Sholahuddin, A. (2017). Students' Difficulties on Science Learning With Prototype Problem-Solving Based Teaching And Learning Material : A Study Evaluation of Development Research. Advances in Social Science, Education and Humanities Research, 100, 279-282.

Saputri, A. C., Sajidan, S., Rinanto, Y., Afandi, A., \& Prasetyanti, N. M. (2019). Improving
Students' Critical Thinking Skills in CellMetabolism Learning Using Stimulating Higher Order Thinking Skills Model. International Journal of Instruction, 12(1), 327-342.

Savery, J. R. (2006). Overview of Problem-Based Learning: Definition and Distinctions, The Interdisciplinary. Journal of ProblemBased Learning, 1 (1), 9-20.

Sigit, D. V., Azrai, E. P., Heryanti, E., Ichsan, I. Z., Jajomi, Y. P., \& Fadrikal, R. (2019). Development Green Consumerism E-Book for Undergraduate Students (Gc-Ebus) as Learning Media in Environmental Learning. Indian Journal of Public Health Research and Development, 10(8), 20262031.

Subali, B. (2010). Penilaian, Evaluasi dan Remediasi Pembelajaran Biologi. Jurusan Pendidikan Biologi Fakultas Matematika Dan Ilmu Pengetahuan Alam Universitas Negeri Yogyakarta: Yogyakarta.

Suharini, E., Kurniawan, E., \& Ichsan, I. Z. (2020). Disaster Mitigation Education in the COVID-19 Pandemic: A Case Study in Indonesia. Sustainability (United States), 13(6), 292-298.

Winarno, S., Muthu, K. S., \& Ling, L. S. (2017). Direct Problem-Based Learning (DPBL): A Framework For Integrating Direct Instruc tion And Problem-Based Learning Approach. International Education Studies, 11(1), 119-126.

Yee, M. H., Yunos, J. M., Othman, W., Hassan, R., Tee, T. K., \& Mohamad, M. M. (2015). Disparity of Learning Styles and Higher Order Thinking Skills among Technical Students. Procedia - Social and Behavioral Sciences, 204(November 2014), 143-152. 